\title{
RESEARCH
}

Open Access

\section{Soil-plant co-stimulation during forest vegetation restoration in a subtropical area of southern China}

\author{
Chan Chen ${ }^{1}$, Xi Fang ${ }^{1,2^{*}}$, Wenhua Xiang ${ }^{1,2}$, Pifeng Lei ${ }^{1,2}$, Shuai Ouyang ${ }^{1,2}$ and Yakov Kuzyakov ${ }^{1,3,4}$
}

\begin{abstract}
Background: Soil and vegetation have a direct impact on the process and direction of plant community succession, and determine the structure, function, and productivity of ecosystems. However, little is known about the synergistic influence of soil physicochemical properties and vegetation features on vegetation restoration. The aim of this study was to investigate the co-evolution of soil physicochemical properties and vegetation features in the process of vegetation restoration, and to distinguish the primary and secondary relationships between soil and vegetation in their collaborative effects on promoting vegetation restoration in a subtropical area of China.
\end{abstract}

Methods: Soil samples were collected to $40 \mathrm{~cm}$ in four distinct plant communities along a restoration gradient from herb (4-5 years), to shrub (11-12 years), to Pinus massoniana coniferous and broadleaved mixed forest (45-46 years), and to evergreen broadleaved forest (old growth forest). Measurements were taken of the soil physicochemical properties and Shannon-Wiener index (SD), diameter at breast height (DBH), height (H), and biomass. Principal component analysis, linear function analysis, and variation partitioning analysis were then performed to prioritize the relative importance of the leading factors affecting vegetation restoration.

Results: Soil physicochemical properties and vegetation features showed a significant trend of improvement across the vegetation restoration gradient, reflected mainly in the high response rates of soil organic carbon (SOC) (140.76\%), total nitrogen (TN) (222.48\%), total phosphorus (TP) (59.54\%), alkaline hydrolysis nitrogen (AN) (544.65\%), available phosphorus (AP) (53.28\%), species diversity (86.3\%), biomass (2906.52\%), DBH (128.11\%), and H (596.97\%). The soil properties ( $\mathrm{pH}, \mathrm{SOC}, \mathrm{TN}, \mathrm{AN}$, and TP) and vegetation features (biomass, DBH, and $H$ ) had a clear coevolutionary relationship over the course of restoration. The synergistic interaction between soil properties and vegetation features had the greatest effect on biomass (55.55\%-72.37\%), and the soil properties contributed secondarily (3.30\%-31.44\%). The main impact factors of biomass varied with the restoration periods.

Conclusions: In the process of vegetation restoration, soil and vegetation promoted each other. Vegetation restoration was the cumulative result of changes in soil fertility and vegetation features.

Keywords: Vegetation restoration, Soil physicochemical properties, Soil organic carbon, Vegetation features, Driving factors

\footnotetext{
* Correspondence: fangxizhang@sina.com

${ }^{1}$ Faculty of Life Science and Technology, Central South University of Forestry and Technology, Changsha 410004, China

${ }^{2}$ Huitong National Field Station for Scientific Observation and Research of

Chinese Fir Plantation Ecosystem in Hunan Province, Huitong 438107, China

Full list of author information is available at the end of the article
}

\section{Springer Open}

(c) The Author(s). 2020 Open Access This article is licensed under a Creative Commons Attribution 4.0 International License, which permits use, sharing, adaptation, distribution and reproduction in any medium or format, as long as you give appropriate credit to the original author(s) and the source, provide a link to the Creative Commons licence, and indicate if changes were made. The images or other third party material in this article are included in the article's Creative Commons licence, unless indicated otherwise in a credit line to the material. If material is not included in the article's Creative Commons licence and your intended use is not permitted by statutory regulation or exceeds the permitted use, you will need to obtain permission directly from the copyright holder. To view a copy of this licence, visit http://creativecommons.org/licenses/by/4.0/. 


\section{Background}

Forest vegetation restoration has become a priority study area in efforts to solve global environmental problems, as highlighted by the Bonn Challenge, a global effort to restore 150 million hectares of degraded land and deforested forests by 2020 (Crouzeilles et al. 2016). Establishing the mechanisms of plant communities in the process of recovery has concentrated mainly on species composition, and their quantitative characteristics and spatial distribution. While these factors are relatively clear (Xiang et al. 2013; Chen et al. 2019), there is still a lack of indepth research on the feedback relationships between plant and soil, and the succession processes and regulation mechanisms of plant communities (Hu et al. 2017; Wang et al. 2018a). The feedback relationship between vegetation and soil has a great impact on the plant community, soil nutrient cycling, and soil and water conservation during vegetation restoration (Demenois et al. 2018). Insights into vegetation-soil feedback relationships are instrumental in predicting future scenarios under varying environmental conditions (van der Putten et al. 2013), as well as in designing measures for vegetation restoration at different succession stages (Huang et al. 2018).

The interactive effects of soil and vegetation suggest that both are always co-evolving and developing, which are recognized as an important mechanism for forest succession and development (van der Putten et al. 2013). The association between soil and aboveground vegetation may shift over the course of restoration (Huang et al. 2015). In the early stage of vegetation restoration, soil resources are the main limiting factors (van Der Maarel and Franklin 2013). Research has shown that the enrichment, spatial distribution, and redistribution of soil nutrients significantly affect the growth, reproduction, distribution, succession, and net primary productivity of plants (Alday et al. 2012). In particular, soil nutrients and water are the key factors in regulating vegetation development, as confirmed by the results of some fertilization experiments (Chang and Turner 2019) and different forest succession series (Huang et al. 2017). In turn, vegetation development can drive changes in the development and maintenance of soil (Huang et al. 2018). Especially in the late stage of vegetation restoration, the accumulation of plant biomass leads to an increase in the return of soil organic carbon (SOC) and nutrients (Gu et al. 2019). Furthermore, soil nutrient storage reflects the balance of the main ecological processes, including nutrients stored in aboveground biomass, nutrients decomposed and returned to soil, and nutrient leaching, these mixed results may cause the complexity of the interaction between soil and vegetation (Huang et al. 2018). Therefore, knowledge of how soil, vegetation and their interaction act on vegetation restoration is of particular importance for predicting future ecological restoration and development.
Subtropical forest covers an extensive area and supports a high level of biodiversity and a global carbon store, particularly in China which has $71 \%$ of the current total forest area in the subtropics according to the MODIS landcover layer for 2012, with abundant rainfall and abundant forest resources (Corlett and Hughes 2015). However, long-term severe human disturbance has a serious effect on subtropical forest ecosystems, with complex topography and climate change resulting in fewer climax forests and a decrease in the functioning of an ecological security barrier (Huang et al. 2018). The Chinese government initiated a series of state-funded forestry ecological projects, including programs to protect natural forests, the Grain to Green program, and the construction of shelterbelts in the middle and upper reaches of the Yangtze River. Consequently, forest vegetation has been rapidly restored, forming a series of secondary vegetation communities at different stages of restoration in this area (Ouyang et al. 2016). During vegetation restoration, aboveground vegetation and soil physicochemical properties gradually change (Zhang et al. 2019). Changes in plant development and soil variables during vegetation restoration have been demonstrated in several studies (Ayma-Romay and Bown 2019; Wang et al. 2018a; Zhang et al. 2019), but the restorative effect of soil or vegetation has rarely been explored, and there is little information on how soil physicochemical properties and vegetation act together to affect vegetation restoration (Chang and Turner 2019). To our knowledge, no studies have addressed the question of the relative importance of the effects of soil, vegetation and their synergism on promoting vegetation restoration. It has therefore become a burning issue to elucidate the coordinated control effect of vegetation restoration, soil, and water on vegetation ecology and restoration ecology (Chang and Turner 2019).

In this study, we followed the succession process of subtropical forest communities, and selected four distinct restoration periods (i.e. 4-5, 10-12, 45-46 years and old growth forest), which represent the four main stages of vegetation restoration in the subtropics of China. We selected permanent plots and determined soil physicochemical properties and vegetation features; i.e. species diversity, biomass, height $(H)$, and diameter at breast height (DBH). Our objective was to investigate how soil physicochemical properties and vegetation features change and how soil and vegetation stimulate vegetation restoration individually and collectively. We formulated two hypotheses: (1) that vegetation restoration would have an obvious positive effect on soil physicochemical properties and vegetation features; and (2) that soil properties and vegetation features would collectively promote vegetation restoration, especially would have a significant impact on biomass. In addition, the main impact factors of biomass would be different in different restoration periods. 


\section{Methods}

\section{Study site}

As shown in Fig. 1, the study site was located in Changsha County $\left(28^{\circ} 23^{\prime}-28^{\circ} 24^{\prime} \mathrm{N}, 113^{\circ} 17^{\prime}-113^{\circ} 27^{\prime} \mathrm{E}\right)$, situated in the middle of Hunan Province, China. The topography features a typical low hilly landscape, at an altitude of $55-260 \mathrm{~m}$ above sea level with an average slope of $18^{\circ}-25^{\circ}$. The climate is characterized by southeast monsoon and a mid-subtropical humid climate with an annual average precipitation of $1416.4 \mathrm{~mm}$ (primarily between April and August) and an annual mean air temperature of $17.3^{\circ} \mathrm{C}$. minimum and maximum air temperatures are $10.3^{\circ} \mathrm{C}$ in January and $39.8^{\circ} \mathrm{C}$ in July and August, respectively. The soils are mainly composed of red earth, which developed from slate and shale and are categorized as Alliti-Udic Ferrosols in the Chinese Soil Taxonomy, corresponding to Acrisol in the World Reference Base for Soil Resources (IUSS Working Group WRB 2006). Evergreen broadleaved forests are the climax and primary vegetation, but have been disturbed in varying degrees by human activities such as firewood collection. Natural forest protection programs in the past two decades have resulted in a variety of vegetation communities at different restoration stages in this area.

\section{Vegetation sampling}

In October 2015, four adjacent vegetation communities, with basically similar environmental conditions (site, slope, soil and climate) as showed in Table 1 were selected to represent a vegetation restoration gradient (using the method of space-for-time substitution). These communities were:

(1) 4-5 yrs. restoration period. Controlled burns and site preparation were carried out in native evergreen broadleaved forest in the winter of 1965 . A Pinus massoniana plantation was established in 1966 without any fertilization during this operation and then clear-cut in 1990. The woodlands were repeatedly cut until 2012. Since that time the vegetation has naturally recovered. The community is dominated by well-grown herbs, presently accompanied by some young shrubs, and belongs to the early stage of restoration according to the succession process of subtropical evergreen broadleaved forest (Xiang et al. 2016).

(2) 10-12 yrs. restoration period. Native evergreen broadleaved forest underwent a prescribed burn in 1965 and deforested to establish a Cunninghamia

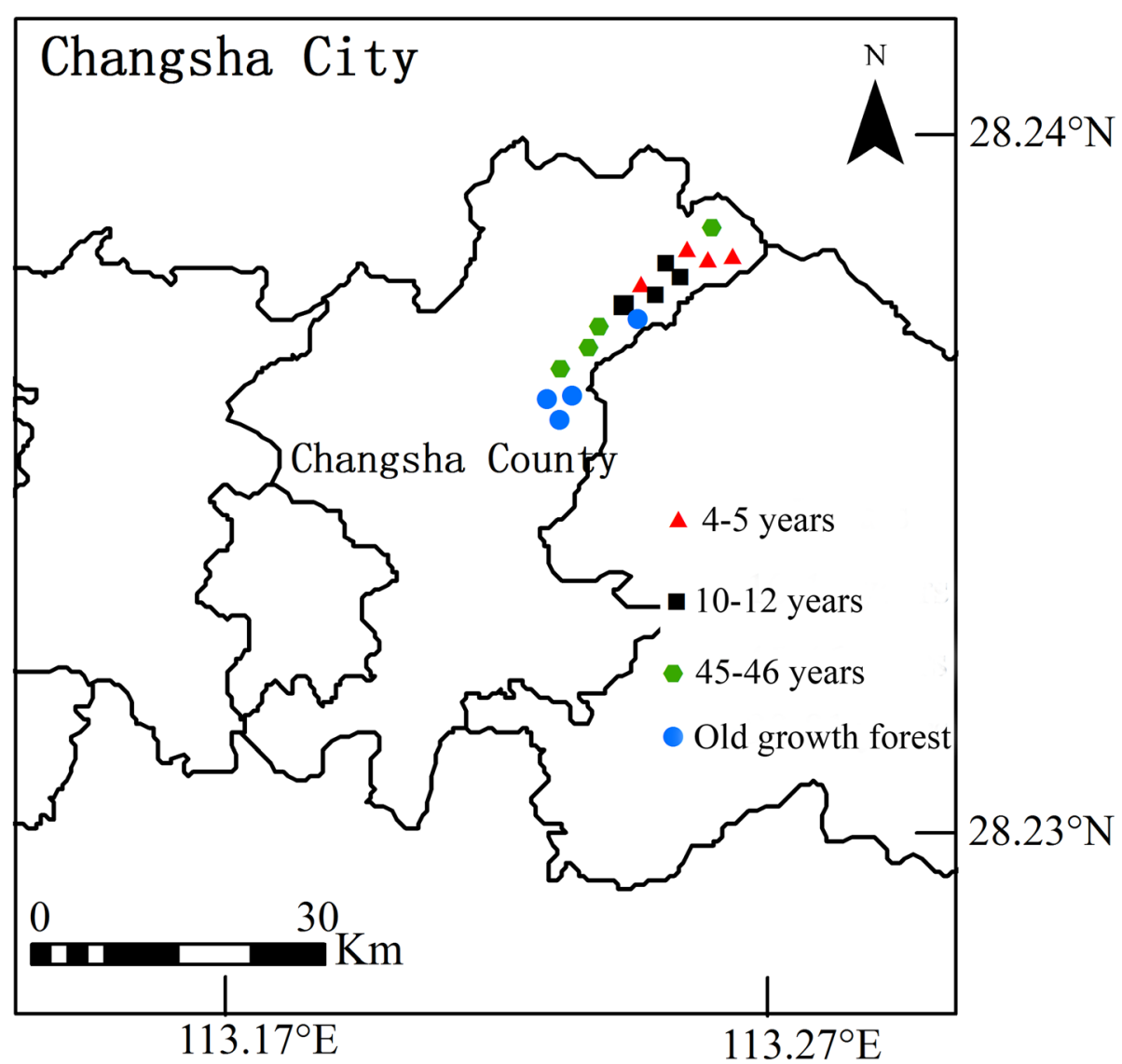

Fig. 1 Location and plot distribution of the study area 
Table 1 Stand characteristics of the four forest types

\begin{tabular}{|c|c|c|c|c|c|c|}
\hline Restoration periods & Dominant plants & $\begin{array}{l}\text { Composition } \\
\text { proportion (\%) }\end{array}$ & $\begin{array}{l}\text { Density of woody } \\
\text { plants (individual. } \mathrm{ha}^{-1} \text { ) }\end{array}$ & Elevation (m) & $\begin{array}{l}\text { Slope } \\
\text { aspect }\end{array}$ & Slope \\
\hline $4-5$ years & $\begin{array}{l}\text { Loropetalum chinensis } \\
\text { Vaccinium bracteatum } \\
\text { Rhododendron mariesii } \\
\text { Quercus fabri } \\
\text { Castanea mollissima } \\
\text { Others (8 species) }\end{array}$ & $\begin{array}{l}34.48 \\
21.55 \\
12.07 \\
7.76 \\
5.17 \\
18.97\end{array}$ & 18,125 & $120-131$ & Southeast & $15^{\circ}-18^{\circ}$ \\
\hline 10-12 years & $\begin{array}{l}\text { Loropetalum chinensis } \\
\text { Cunninghamia lanceolata } \\
\text { Quercus fabri } \\
\text { Vaccinium bracteatum } \\
\text { Litsea cubeba } \\
\text { Others (16 species) }\end{array}$ & $\begin{array}{l}17.47 \\
14.85 \\
12.66 \\
12.66 \\
11.35 \\
31.01\end{array}$ & 7633 & $120-135$ & Northwest & $18^{\circ}-22^{\circ}$ \\
\hline 45-46 years & $\begin{array}{l}\text { Pinus massoniana } \\
\text { Lithocarpus glaber } \\
\text { Loropetalum chinensis } \\
\text { Adinandra millettii } \\
\text { Camellia cuspidata } \\
\text { Others (22 species) }\end{array}$ & $\begin{array}{l}39.69 \\
25.52 \\
11.06 \\
3.59 \\
3.11 \\
17.03\end{array}$ & 17,396 & $135-160$ & Southwest & $18^{\circ}-20^{\circ}$ \\
\hline Old growth forest & $\begin{array}{l}\text { Lithocarpus glaber } \\
\text { Adinandra millettii } \\
\text { Cunninghamia lanceolata } \\
\text { Cyclobalanopsis } \\
\text { Eurya muricata } \\
\text { Others (31 species) }\end{array}$ & $\begin{array}{l}38.78 \\
18.70 \\
5.82 \\
5.36 \\
5.06 \\
26.28\end{array}$ & 20,785 & $225-254$ & Northwest & $20^{\circ}-22^{\circ}$ \\
\hline
\end{tabular}

lanceolata plantation in 1966. This C. lanceolata plantation was clear-cut in 1989 . The woodlands were logged every 3 to 5 years until 2004. The vegetation has naturally recovered to form a shrub community with well-grown shrubs and belongs to midrestoration stage according to the succession process of subtropical evergreen broadleaved forest (Xiang et al. 2016). However, the shrub community has no obvious arbor layers and herbaceous plant is relatively infrequent.

(3) 45-46 yrs. restoration period. This period represents the secondary stage of mid-restoration. Native evergreen broadleaved forest was deforested in the early 1970s, and then naturally recovered to coniferous and broadleaved mixed forest. The communities are now about 45-50 years old, and have abundant seedlings and saplings, with larger plant density. However, the proportion of large diameter individuals is relatively low.

(4) Old growth forest (representing the late stage of restoration). Native evergreen broadleaved forest has been well protected against human disturbances. According to the survey with local residents, this forest has been more than 90 years.

In October 2015, we randomly established 4 fixed sample plots for long-term observation in each restoration period (Fig. 1). In the $4-5$ and $10-12$ years restoration periods, the plots were set at $20 \mathrm{~m} \times 20$ $\mathrm{m}$. In the 45-46 years restoration periods and old growth forest, the plots were established at $30 \mathrm{~m} \times$ $30 \mathrm{~m}$. The 4 fixed plots in each restoration period were set in different mountains as far as possible, and the space distance between the two plots was more than $1000 \mathrm{~m}$. To investigate the floristic components and tree spatial patterns of the forests, each plot $(20 \mathrm{~m} \times 20 \mathrm{~m})$ in the $4-5$ and $10-12$ years restoration periods was subdivided into four subplots (10 $\mathrm{m} \times 10 \mathrm{~m})$, and each plot $(30 \mathrm{~m} \times 30 \mathrm{~m})$ in the $45-46$ years restoration periods and old growth forest was subdivided into nine subplots $(10 \mathrm{~m} \times 10 \mathrm{~m})$.

\section{Species diversity measurement}

Species identities were recorded and measurements were taken of total $H$, the lowest live branch and crown width, and $\mathrm{DBH}$ for all individuals with $\mathrm{DBH}>1 \mathrm{~cm}$ in each plot. The data were used to calculate vegetation structural parameters of the different restoration periods; i.e. density of main tree species, average DBH, and average $H$. The ShannonWiener index (SD) was used to quantify the diversity of woody plants species in each plant community with the equation below (Madonsela et al. 2018).

$$
\mathrm{SD}=-\sum_{i=1}^{n} P_{i} \ln P_{i}
$$

In Eq. 1, $n$ represents the total number of species in the community, and $P_{i}$ represents the relative frequency 
of species $i$ in the community. Table 1 summarizes the characteristics and site factors of each community.

\section{Biomass measurement}

Based on community surveys, biomass was measured by the harvest method and calculated by establishing relative growth equations of the organic biomass of the main tree species. For the 4-5 years restoration period, we collected all vegetation (shrubs, vines, herbs) in $2 \mathrm{~m} \times 2 \mathrm{~m}$ quadrats which were on plot peripheries and then classified the same plants according to the following criteria: shrubs were composed of fruit, leaf, branch, stem, and root; vines were composed of fruit, leaf, stem, and root; and herbs were composed of aboveground and underground parts. A $1 \mathrm{~m} \times 1 \mathrm{~m}$ quadrat was set up at the center of each $10 \mathrm{~m} \times 10 \mathrm{~m}$ subplot to determine litter biomass. All litter was collected from the ground in these quadrats and transported to the laboratory. Determined samples were freshly weighed and then oven-dried at $85^{\circ} \mathrm{C}$ to a constant weight to measure their dry mass for estimating biomass per plot area.

For the 10-12 years restoration period, according to the average $\mathrm{DBH}$ and average $H$ of the shrub $(>1.5$ $\mathrm{m})$, and with the aim of ensuring that at least 3 average sample trees per dominant tree species were collected, 3 sample trees were selected and collected for each dominant tree in each plot periphery to determine fresh weight. Shrub samples were composed of fruit, leaf, branch, stem, and root. After oven-drying at $85^{\circ} \mathrm{C}$ to a constant weight, we determined moisture content and calculated each biomass component of each tree species, establishing their relative growth equations to calculate biomass per shrub plant (Table 2). The biomass determination of shrubs (below $1.5 \mathrm{~m}$ ), vines, herbaceous layers, and litter layer used the same method as the 4-5 years restoration period. Finally, estimated biomass per plot area was based on data from community surveys.

For the 45-46 years restoration period, 3 sample trees were selected for each dominant tree in each plot periphery according to average $\mathrm{DBH}$ and average $H$, with the same aim as that for the $10-12$ years restoration period. Stratified samples $(1.3 \mathrm{~m}, 3.6 \mathrm{~m})$ were collected for the aboveground part and complete samples were excavated for the underground part (within $1.5 \mathrm{~m}$ of the tree stump) to measure fresh weight. Tree samples were composed of leaf, branch, stem, and root, in which root included fine root $(<0.2 \mathrm{~cm})$, rootlet $(0.2-0.5 \mathrm{~cm})$, thick root $(0.5-2.0 \mathrm{~cm})$, large root $(>2.0 \mathrm{~cm})$, and root apex. After determining fresh weight, samples were oven-dried at $85^{\circ} \mathrm{C}$ to a constant weight to calculate moisture content. We then estimated each biomass component of each tree species, established their relative growth equations and then calculated the biomass per tree plant (Table 2 ). The same methods as above were used to determine the biomass of shrubs, vines, herbaceous layers, and litter layer. Estimated biomass per plot area was based on data from community surveys. For the old growth forest, the relative growth equations for the main tree species in the tree layer were established using a similar method as the $45-46$ years restoration period. However, because of the ban on logging in the old growth forest, the general growth equations of Cyclobalanopsis, deciduous broadleaf, evergreen broadleaf, and C. lanceolata, which were established by Ouyang et al. (2016) and Liu et al. (2010), were also used to estimate the biomass in the tree layer (Table 2).

\section{Soil sampling and analysis}

Each permanent plot was divided into 3 equal grids of cells along the diagonal for soil sampling. In each cell, soil profile characteristics were surveyed in 2015 to illustrate the consistency and comparability of soil background in different vegetation restoration periods, as shown in Table 3. Soil samples were taken by using cylindrical cores with a volume of $200 \mathrm{~cm}^{3}$ collected at depths of $0-10,10-20,20-30$, and $30-$ $40 \mathrm{~cm}$ in December 2015, and in April, June, and October 2016.

Soil samples from three cells at the same depth within a plot were mixed into a composite sample. Plant roots, debris, and gravels were cleared. Soil samples were air-dried and sieved through a 2-mm mesh for soil $\mathrm{pH}$, available phosphorus (AP), and available potassium (AK); through a 1-mm mesh for soil alkaline hydrolysis nitrogen (AN); and through a 0.25-mm mesh for soil SOC, TN, total phosphorus (TP), total potassium (TK), total calcium (Ca), and total magnesium $(\mathrm{Mg})$ determinations. The following properties were determined in the soil samples:

(1) Bulk density (BD) was calculated using weights of the dried soil sample from the known cylindrical core volume. (2) $\mathrm{pH}$ value was analyzed in a soil-towater (deionized) ratio of 1:2.5 using a $\mathrm{pH}$ meter (FE20, Mettler Toledo, Switzerland). (3) SOC content was determined by the $\mathrm{K}_{2} \mathrm{Cr}_{2} \mathrm{O}_{7}-\mathrm{H}_{2} \mathrm{SO}_{4}$ oxidation method. (4) TN content was determined using a semi-micro Kjeldahl method (Bremner 1996). (5) TP, $\mathrm{TK}, \mathrm{Ca}$, and $\mathrm{Mg}$ were extracted via aqua regia and 1 : $1 \mathrm{HCl}$. After extraction, TP was determined by spectrophotometry and $\mathrm{TK}, \mathrm{Ca}$, and $\mathrm{Mg}$ by atomic emission spectrometry with inductively coupled plasma (ICP-OES) using a Perkin Elmer Optima 7300DV optical emission spectrometer (Nicia et al. 2018). (6) For 


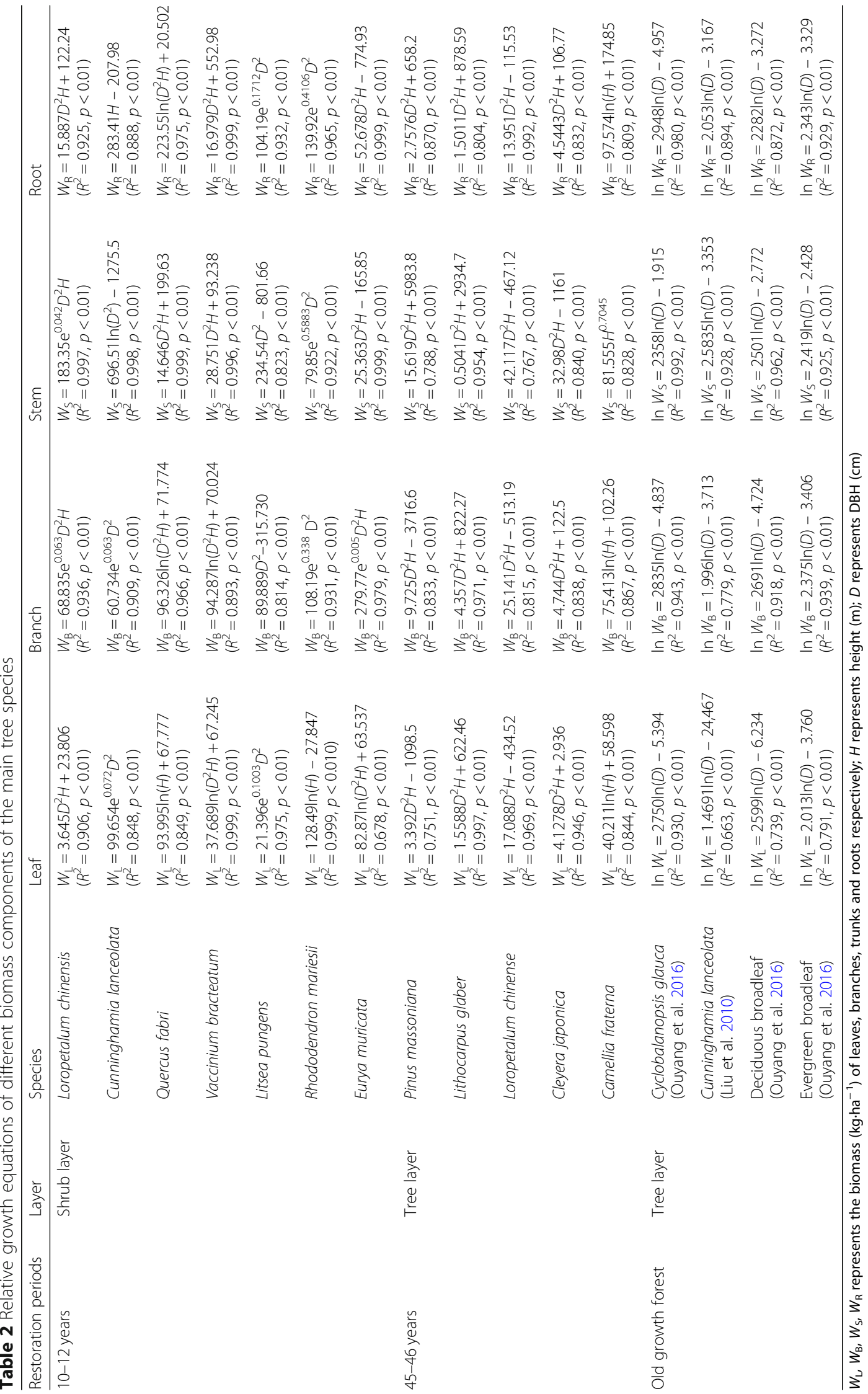




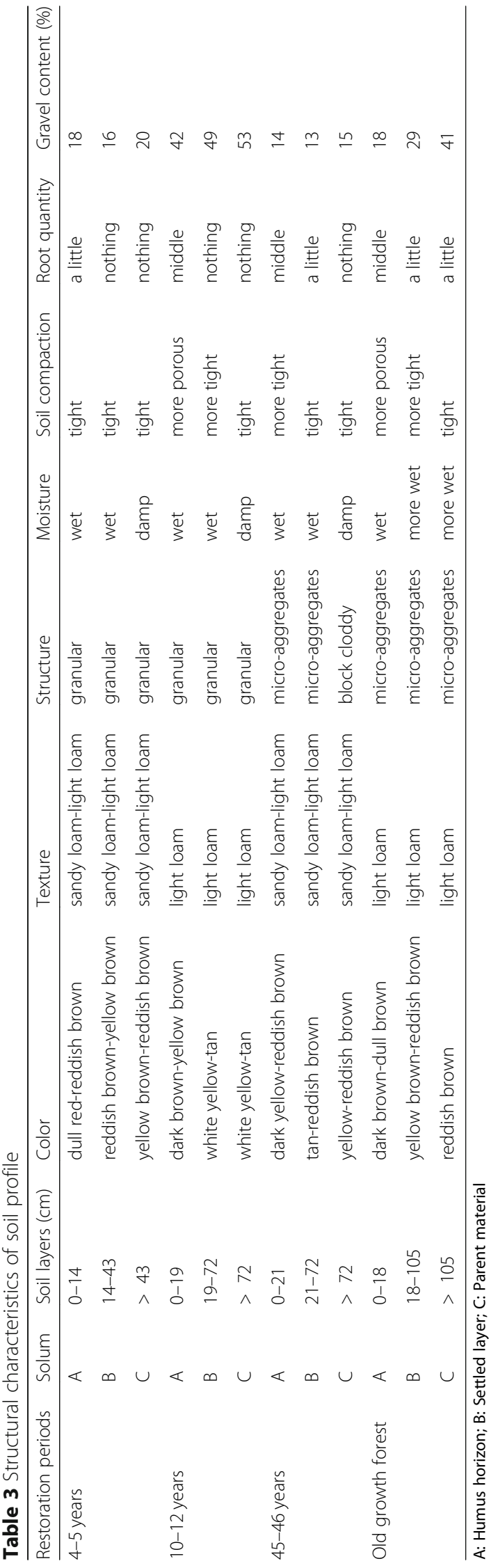


AN and AK, we used the alkaline diffusion method and the ammonium acetate extraction flame spectrophotometer method (ISSCAS 1978). (7) For AP, we used the Olsen method (Olsen et al. 1983).

\section{Statistical analysis}

For data processing, we used the Microsoft Excel package (Office 2010). All statistical analyses were conducted using the $\mathrm{R}$ statistical software package ( $\mathrm{R}$ Development Core Team 2016). In order to reflect the annual average situation of the soil properties, the arithmetic mean of four seasons in the same soil layer of each plot was calculated. At the same time, taking into account the great changes between soil layers of each variable, a weighted average of four soil layers was carried out. The parameter content of a soil layer as a percentage of the sum of four soil layers $\left(f_{i}\right)$ was calculated using Eq. 2, and the weighted average $\left(X_{0}\right)$ was calculated using Eq. 3.

$$
\begin{aligned}
& f_{i}(\%)=\frac{L_{i}}{\sum_{i=1}^{n} L_{i}} \times 100 \\
& X_{0}=\sum_{i=1}^{n}\left(X_{i} \times f_{i}\right)
\end{aligned}
$$

In Eqs. 2 and 3, $n$ represents the number of soil layers; $L_{i}$ represents the parameter content of a soil layer; and $X_{i}$ represents the parameter content of a soil layer.

The response rate was used to determine the effects of restoration periods on soil properties and vegetation features, calculated by Eq. 4 .

$$
\text { Response rate }(\%)=\frac{X_{2}-X_{1}}{X_{1}} \times 100
$$

In Eq. 4, $X_{1}$ represents one of the soil properties or vegetation features in the $4-5,10-12$, and $45-46$ years restoration periods, and $X_{2}$ represents one of that in the old growth forest. In this study, only $X_{1}$ in the $4-5$ years restoration period is selected to reflect the extent of variables variation over the whole vegetation restoration. A positive value indicates an increase, a negative value indicates a decrease, and greater absolute values indicate greater change. Figure 2 was drawn by the geom_histogram function of ggplot2 package in the R statistical software. Before drawing, the values were normalized to a proportion of maximum value $(=1)$ and by min-max normalization to keep a common scale ranging from 0 to 1 (Jain et al. 2005). The min-max normalization was calculated by Eq. 5 .

$$
x^{\prime}=\frac{\left(x-x_{\mathrm{Min}}\right)}{x_{\mathrm{Max}}-x_{\mathrm{Min}}}
$$

Principal component analysis (PCA) was used to determine the main factors in soil properties and vegetation features influencing vegetation restoration, and the correlations between soil properties and vegetation features. The PCA was implemented using the prcomp function and drawn by the ggplot 2 package of the $\mathrm{R}$ software. The selection criteria for principal components included a cumulative contribution rate over $85 \%$ and eigenvalues greater than 1 . Indicator whose absolute value of a loading matrix was greater than 0.7 was selected as the dominant factors (Armstrong 1967) for vegetation restoration. The cosine values of the angles between variables indicate relationship strength; angles ranging from $0^{\circ}$ to $90^{\circ}$ indicate variables have positive correlations, and $90^{\circ}$ to $180^{\circ}$ indicate negative correlations.

Based on the results of PCA, we used linear function analysis to further examine the significant correlations of soil properties and vegetation features. Before fitting the linear function, data were normalized by min-max normalization for unifying dimensions, and also calculated using Eq. 5. It was assumed that the relation between soil properties and vegetation features can be expressed by Eq. 6 , where $k$ represents slope, and $b$ represents a constant.

$$
y=k x+b
$$

Figure 3 was produced via the $l m$ function and plot function in R. Variation partitioning analysis (VPA) was performed to quantify the relative contributions of soil factors, vegetation factors and their joint action to changes in biomass by the varpart function of vegan package. Before VPA, the suitably independent variables with the variance inflation factor (VIF) $<3$ were selected by using the car package (Yang et al. 2017), and then the factor analysis (FA) were used to reduced soil factors and vegetation factors into a common factor respectively using psych package in R. Figure 4 was drawn by the geom_bar function of ggplot2 package in R. Following the results of PCA and linear function analysis, we conducted a stepwise regression analysis (SRA) to analyze, screen, and eliminate variables that cause multicollinearity, and to determine the leading impact factors of biomass per restoration period. The SRA was performed by the step function in R.

\section{Results}

Changes in vegetation features and soil physicochemical properties during vegetation restoration

Vegetation features and soil physicochemical properties varied in the regularity of change according to the 


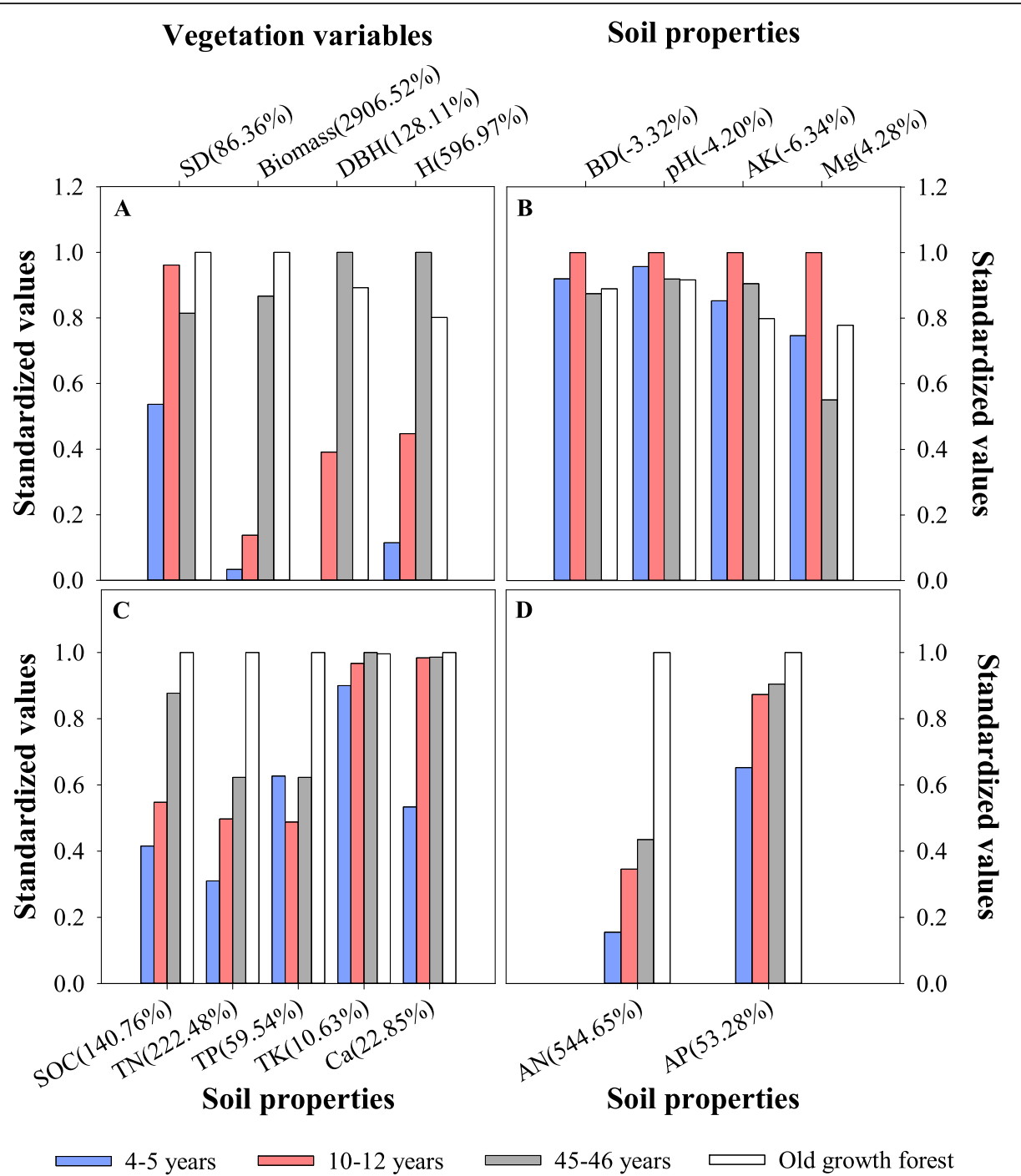

Fig. 2 Changes in soil physical and chemical properties and vegetation features per vegetation restoration period. Soil properties (weighted mean, $n=4)$ : bulk density (BD), pH value $(\mathrm{pH})$, organic carbon (SOC), total $\mathrm{N}(\mathrm{TN})$, total $\mathrm{P}(\mathrm{TP})$, total $\mathrm{K}(\mathrm{TK})$, total $\mathrm{Ca}(\mathrm{Ca})$, total Mg (Mg), alkaline hydrolysis N (AN), available P (AP), and available K (AK). Vegetation features (mean, $n=4)$ ): species diversity, biomass, diameter at breast height $(\mathrm{DBH})$ and height $(H)$. The values were normalized to the proportion of maximum value $(=1)$. Values in brackets are response rates from $4-5$ years to old growth forest (\%)

different restoration periods (Fig. 2). Vegetation features (species diversity, biomass, DBH, and $H$ ) increased remarkably with vegetation restoration, and the response rates increased by $86.36 \%, 2906.52 \%, 128.11 \%$, and $596.97 \%$ respectively. Specifically, the highest values of species diversity and biomass were observed in the old growth forest, and the highest values of $\mathrm{DBH}$ and $H$ were observed in the 45-46 years restoration period. The change trends of biomass, $\mathrm{DBH}$, and $H$ were basically the same (Fig. 2a). The maximum values of soil BD, $\mathrm{pH}$ value, $\mathrm{Mg}$ content, and $\mathrm{AK}$ content occurred in the $10-12$ years restoration period. $\mathrm{BD}, \mathrm{pH}$, and $\mathrm{AK}$ content showed a decreasing trend whereas $\mathrm{Mg}$ showed an increasing trend with vegetation restoration (Fig. 2b). The response rates of $\mathrm{BD}, \mathrm{pH}$, and $\mathrm{AK}$ were negative but changed slightly. However, the contents of SOC, TN, $\mathrm{TP}, \mathrm{TK}, \mathrm{Ca}, \mathrm{AN}$, and AP increased with vegetation restoration, and their maximum values were recorded in the old growth forest except for TK (Fig. 2c and d). The response rates of $\mathrm{SOC}, \mathrm{TN}, \mathrm{TP}, \mathrm{TK}, \mathrm{Ca}, \mathrm{AN}$, and $\mathrm{AP}$ ranged from $10.63 \%$ to $544.35 \%$, with AN having the highest response rate of $544.65 \%$, followed by $\mathrm{TN}$ (222.48\%) and SOC (140.76\%).

\section{Factors of soil properties and vegetation features} influencing vegetation restoration and their relationships The results of PCA showed that soil properties and vegetation features explained $81.54 \%$ of the variations 


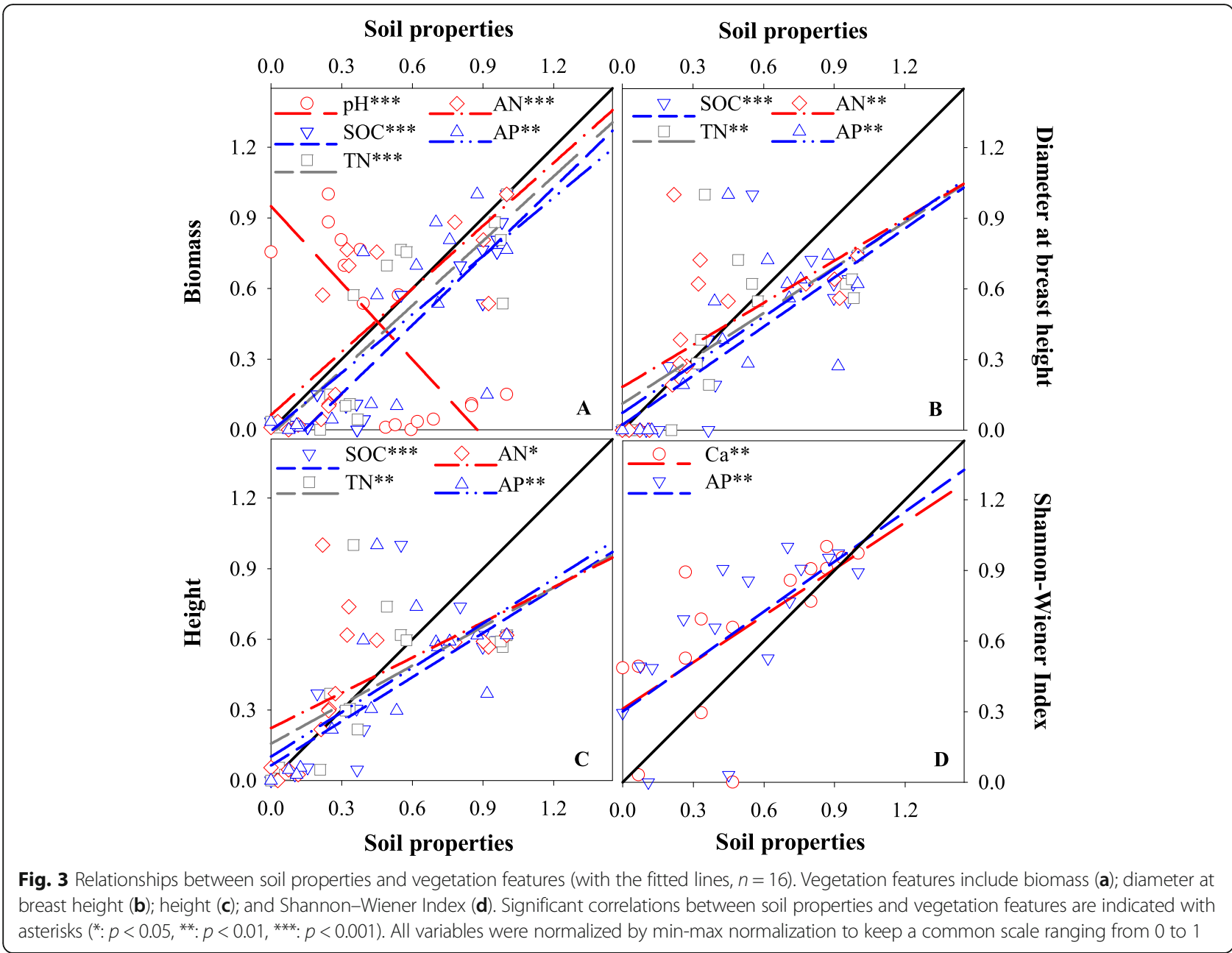

$(\mathrm{PC} 1=48.70 \% ; \quad \mathrm{PC} 2=20.21 \% ; \quad \mathrm{PC} 3=12.63 \%)$, revealing three main correlated variable groups of vegetation restoration (Fig. 5). There was a strong positive correlation between PC1 and SOC, TN, AN, AP, biomass, DBH, and $H$, and a negative correlation between $\mathrm{PC} 1$ and soil $\mathrm{pH}$. As shown in Fig. 5, the successful discrimination of the 45-46 years restoration periods and old growth forest from other periods were strongly influenced by PC1. In the selection criteria, $\mathrm{PC} 2$ was correlated positively with $\mathrm{Mg}$, and PC3 with TK. Figure 5 also shows that the successful discrimination of the 10-12 years restoration period from the 4-5 years restoration period was highly influenced by PC2 and PC3. Therefore, the key factors influencing vegetation restoration can be summarized as soil water and fertilizer conservation capacity $(\mathrm{pH})$, organic matter (SOC), macro nutrients (TN, TK), medium nutrients $(\mathrm{Mg})$, available nutrients ( $\mathrm{AN}, \mathrm{AP})$, and the plant community growth situation (biomass, $\mathrm{DBH}, H$ ).

The results of PCA also showed that biomass, DBH, and $H$ had significant correlations with each other, while species diversity was weakly correlated with them. Biomass, DBH, and $H$ had similar relationships with soil factors
(Fig. 5). Specifically, the order of high positive correlations with soil factors was $\mathrm{SOC}>\mathrm{TN}>\mathrm{AN}>\mathrm{TP}>\mathrm{AP}$, whereas a high negative correlation was with soil $\mathrm{pH}$. The order of factors with high positive correlations with species diversity was $\mathrm{Ca}>\mathrm{AP}>\mathrm{AN}>\mathrm{TN}$ (Fig. 5).

As shown in Fig. 3, the results of linear function analysis revealed that as $\mathrm{SOC}, \mathrm{TN}, \mathrm{AN}$, and $\mathrm{AP}$ increased, biomass, $\mathrm{DBH}$, and $H$ significantly increased $(p<0.05)$. However, biomass decreased remarkably with the increased in $\mathrm{pH}$ $(p<0.001)$. With the increasing of $\mathrm{Ca}$ and AP, species diversity showed a great increase trend $(p<0.01)$.

\section{Effects of soil properties and vegetation features (DBH and $H$ ) on biomass variation}

The VPA results showed that the combination of soil properties and vegetation features explained $90.51 \%$ of the variation in biomass in the whole restoration process, and explained $83.44 \%, 99.99 \%, 99.99 \%$, and $98.15 \%$ of the variation in $4-5,10-12,45-46$ years vegetation periods and old growth forest, respectively (Fig. 4). The interaction of soil properties and vegetation features all had the highest explanation for the variation in 


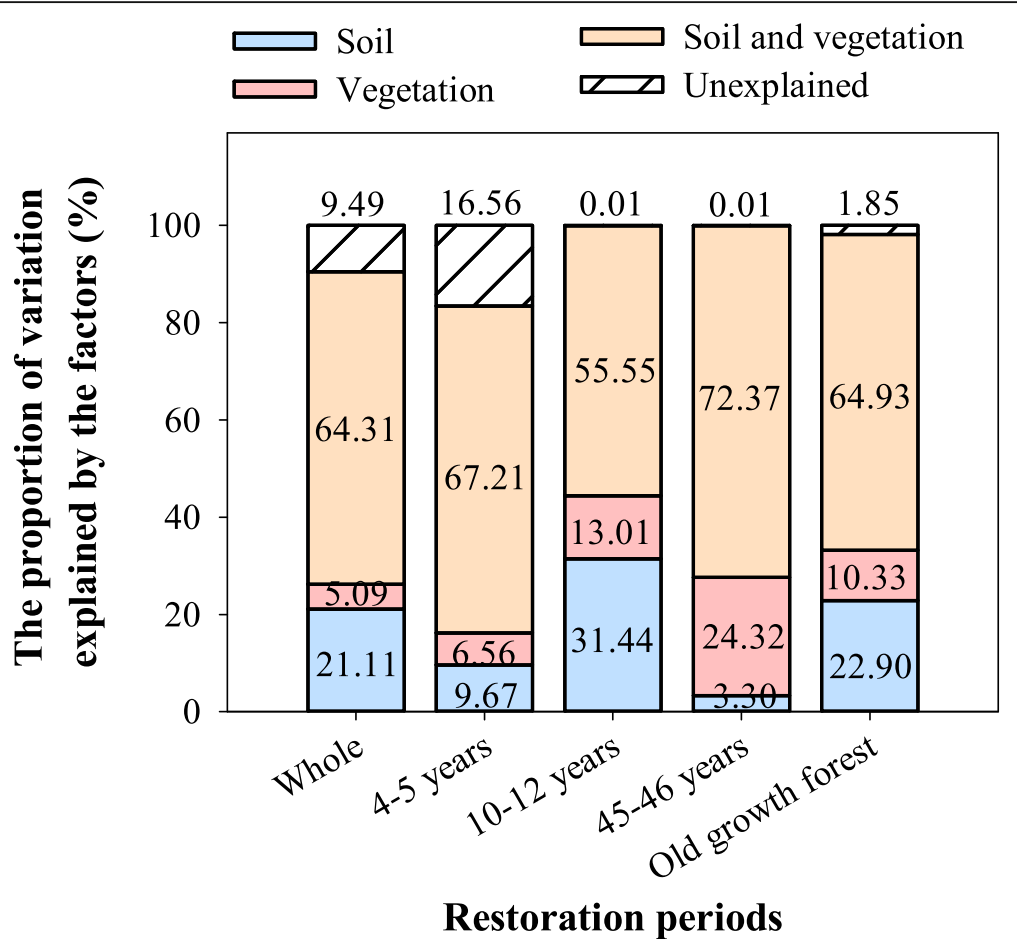

Fig. 4 Variation partition analysis of the effects of soil properties and vegetation features on biomass. The numbers in each bar indicate proportions of variation of the biomass explained by soil properties (sky blue) and vegetation features (pink) individually and collectively (light orange) or not explained by either factor (white)

biomass, ranging from $55.55 \%-72.32 \%$. The soil properties alone explained $3.30 \%-31.44 \%$ of the variation, and the vegetation features alone explained $5.09 \%-24.32 \%$, among which soil properties had higher individual explanation than vegetation features except the $45-46$ years restoration period.

The results of SRA (Table 4) indicated that the factors influencing biomass in the whole restoration process included DBH and SOC. The fitting equation was: $y_{\text {bio- }}$ mass $=7151.27 x_{\mathrm{DBH}}+7595.62 x_{\mathrm{SOC}}\left(R^{2}=0.914, p=0.000\right)$. However, there were different factors influencing the biomass per restoration periods. In the $4-5$ years restoration period, SOC was the only dominant factor, and the fitting equation was: $y_{\text {biomass }}=-966.94 x_{\mathrm{SOC}}\left(R^{2}=0.903\right.$, $p=0.050) . H, \mathrm{pH}$, and AP were the main influential factors in the 10-12 years restoration period. The fitting equation was: $y_{\text {biomass }}=15,620.74 x_{H}-1.00 x_{\mathrm{pH}}-3484.06 x_{\mathrm{AP}} \quad\left(R^{2}=\right.$ $0.990, p=0.000) . H$ and $\mathrm{pH}$ were the main factors in the $45-46$ years restoration period $\left(y_{\text {biomass }}=-10,432.46 x_{H}+\right.$ $\left.14,071.07 x_{\mathrm{pH}} ; R^{2}=0.990, p=0.000\right)$. In the old growth forest, SOC, TN and AP were the impacting factors $\left(y_{\text {bio- }}\right.$ mass $=45,060.13 x_{\mathrm{SOC}}+18,771.33 x_{\mathrm{TN}}+26,287.80 x_{\mathrm{AP}} ; \quad R^{2}=$ $0.990, p=0.000$ ). In all periods, AN was not screened into the regression equation.

\section{Discussion}

Soil physicochemical properties during vegetation restoration

Our results showed that soil BD decreased, and the contents of SOC, TN, TP, TK, Ca, AN, and AP increased with vegetation restoration (Fig. 2), indicating that soil physicochemical properties improved significantly. These results are partially consistent with our hypothesis and with the results of Zhang et al. (2019).

The rapid recovery of SOC at our study site has been proven to be affected by plant biomass and soil nutrients (Gu et al. 2019). The response rate of SOC $(140.76 \%)$ in this research was higher than the results under semi-arid conditions (71\%) recorded by Boix-Fayos et al. (2009), which may be due to the more humid conditions in subtropical regions. Consistent with the rapid accumulation of SOC, the rates of change in $\mathrm{TN}$ and $\mathrm{AN}$ were greater than the SOC change. This result differs from the results of studies in the same subtropical area of southwest China (Xu et al. 2018), which may be due to differences in the degree of degradation and type of vegetation system. Additionally, soil $\mathrm{N}$ is also input from other $\mathrm{N}$ sources, such as atmospheric $\mathrm{N}$ deposition, and symbiotic N fixation by legumes (Alday et al. 2012). This explains why the recovery rates of $\mathrm{TN}$ and $\mathrm{AN}$ were greater than SOC. Our results for the increase in TP and 


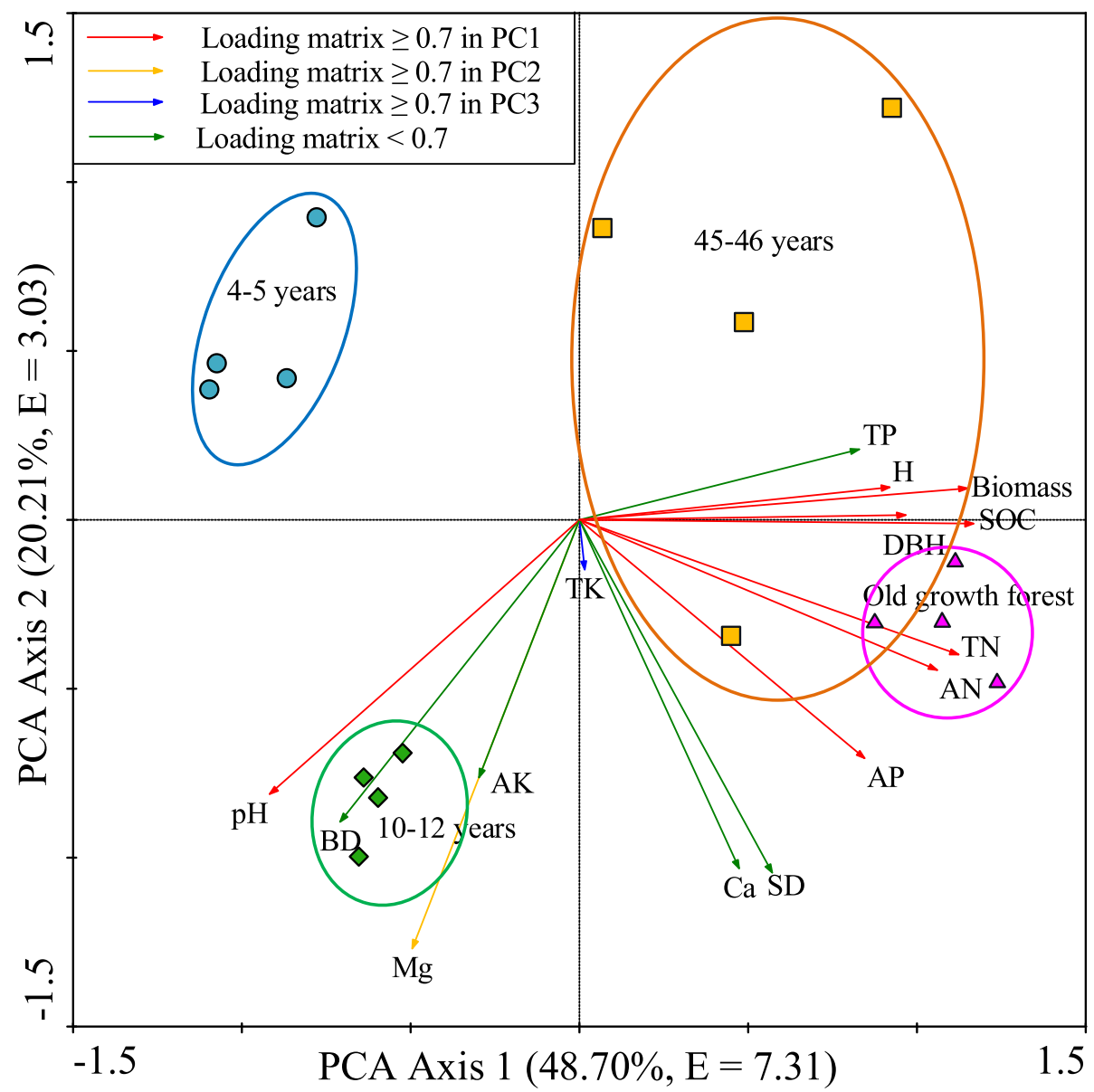

Fig. 5 Variables ordination diagram of PCA for the first three principal component axes $(n=16)$. E indicates eigen values; percentages in brackets indicate contribution rate. The cumulative contribution rate of 3 principal components was over $80 \%$ with eigenvalues greater than 1 . Absolute value of a loading matrix greater than 0.7 indicates that variable has a significant contribution to a principal component. The distance of arrows from the center indicates the strength of the contributing variable to principal component. The cosine values of the angles between variables indicate relationship strength; angles ranging from $0^{\circ}$ to $90^{\circ}$ indicate variables have positive correlations, and $90^{\circ}$ to $180^{\circ}$ indicate negative correlations

AP contents are consistent with the results of Zhang et al. (2019), who proposed that soil TP and AP contents gradually increase with the composition of tree species, annual litter yield, and SOC content along with the development of a forest's second succession. This is also supported by the significant positive correlation of soil TP and AP contents with the species diversity, biomass, and contents of SOC, TN and AN observed in this study (Fig. 5), which suggests that the accumulation of SOC improves soil nutrients during vegetation restoration (Zhang et al. 2019).

The variation ranges of $\mathrm{BD}$ and $\mathrm{pH}$ in the subtropical regions of China are $0.97-1.47 \mathrm{~g} \cdot \mathrm{cm}^{-3}$ and $4.5-6.0$, respectively (Hunan Provincial Department of Agriculture

Table 4 Stepwise regression of corresponding factors for biomass $(n=16)$

\begin{tabular}{|c|c|c|c|c|c|c|c|c|c|}
\hline \multirow{2}{*}{$\begin{array}{l}\text { Restoration } \\
\text { periods }\end{array}$} & \multicolumn{7}{|c|}{ Regression coefficient } & \multirow[t]{2}{*}{$R^{2}$} & \multirow[t]{2}{*}{$p$} \\
\hline & $\mathrm{DBH}$ & $H$ & $\mathrm{pH}$ & SOC & $\mathrm{TN}$ & AN & AP & & \\
\hline Whole & 7151.27 & - & - & 7595.62 & - & - & - & 0.914 & 0.000 \\
\hline $4-5$ years & - & - & - & -966.94 & - & - & - & 0.903 & 0.050 \\
\hline 10-12 years & - & $15,620.74$ & -1.00 & - & - & - & -3484.06 & 0.990 & 0.000 \\
\hline $45-46$ years & - & $-10,432.46$ & $14,071.07$ & - & - & - & - & 0.990 & 0.000 \\
\hline Old growth forest & - & - & - & $45,060.13$ & $18,771.33$ & - & $26,287.80$ & 0.990 & 0.000 \\
\hline
\end{tabular}

"-" indicates that the factors were removed by stepwise regression; $R^{2}$ indicates adjustment decision coefficient 
1989). Our results were in the variation ranges. All the $\mathrm{pH}$ samples in our study indicate that soil $\mathrm{pH}$ (4.544.96) was lower than the results of Takoutsing et al. (2016), being formed by a moderate ferrallitic effect under high temperature and high humidity conditions in subtropical regions (Li et al. 2012b). Meanwhile, decreasing soil $\mathrm{BD}$ and $\mathrm{pH}$ has also been attributed to the accumulation of organic matter, which is conducive to the formation of soil aggregates and the improvement of soil microbial activity (Bienes et al. 2016). This in turn releases a large number of small molecular organic acids during the decomposition of organic matter (van Breemen et al. 1984), resulting in a decline in soil BD and $\mathrm{pH}$ values. The SOC in our study increased and showed negative relationships with $\mathrm{BD}$ and $\mathrm{pH}$ during vegetation restoration (Fig. 5). In addition, this study shows that biomass stimulated the decrease in soil $\mathrm{pH}$ during vegetation restoration (Fig. 3). The accumulation of biomass led to increased biomass in the roots, almost certainly reflecting the development of the vegetation community from annual plant species to perennial plants, which is more conducive to the release and accumulation of the various acid exudates (Pang et al. 2018). Although BD and $\mathrm{pH}$ showed a general declining trend, their values reached a peak in the 10-12 years restoration period (Fig. 2). These results may be caused by a combination of factors (i.e. soil texture, vegetation types and soil acid-base equilibrium). Firstly, as herbs developed into shrubs in our study site, the erosion effect of rainwater on soil silt and clay particles resulted in a high proportion of sand particles in the $10-12$ years restoration period, reflecting the transformation of soil texture to sandy soil with high BD (Wang et al. 2018b). Secondly, changes in vegetation types could be a major driver behind the difference in cations absorption of the vegetation and consequent variation in the proportions of soil cations (Gu et al. 2019). From soil acid-base equilibrium, the increase in cations (especially $\mathrm{Mg}$ and $\mathrm{AK}$ ) suggests that the soil $\mathrm{H}^{+}$was replaced by increased alkaline ions (Berthrong et al. 2009). Due to the similar soil parent materials at different restoration stages, soil $\mathrm{Ca}$, $\mathrm{Mg}$, and $\mathrm{K}$ contents, which are all derived from parent rock materials, change little in response rates during vegetation restoration (Takoutsing et al. 2016).

\section{Vegetation development during restoration periods}

In our study, species diversity increased with an $86.36 \%$ recovery rate as restoration progressed, and these results are consistent with the results of Wang et al. (2018a). The amount of biomass increased significantly with the greatest recovery rate $(2906.52 \%)$ over the old growth forest, followed by $H(596 \%)$ and $\mathrm{DBH}(128 \%)$ in the 45-46 years period. These results are partially consistent with our hypothesis and are very similar to the results of Hu et al. (2017).

Improvements to the soil environment can provide community habitat quality which then promotes the enrichment of community diversity (Huang et al. 2015). Ca content had a significant positive effect on species diversity (Fig. 3), reflected in the following mechanisms. Firstly, $\mathrm{Ca}^{2+}$ has the function of maintaining the homeostasis of intracellular ions, especially in acidic soil where higher $\mathrm{Ca}^{2+}$ content can counterbalance the toxicity of aluminum ions for plants, further improving plant resistance to adversity and being conducive to the improvement of community diversity (Roem et al. 2002). Secondly, the increase in soil Ca content alongside vegetation restoration can be instrumental in the coexistence of species with different $\mathrm{Ca}$ requirements and the settlement of calcium-loving species (Hooper 1998). Additionally, soil $\mathrm{P}$ determines the species composition of a vegetation community (Huang et al. 2015); thus, soil AP content was considered as another major factor determining species diversity increase (Fig. 3).

In our study, biomass, $\mathrm{DBH}$, and $H$ had basically the same changing trend, and were all significantly affected by SOC, TN, AN, and AP contents (Figs. 4 and 5). This is consistent with Brandies et al. (2009), who demonstrated that there are significant positive growth rates and similar effect factors between biomass, DBH, and $H$ in a general case. Data analysis of our study site confirmed that the percentages of individual trees with $\mathrm{DBH}$ greater than $8 \mathrm{~cm}$ and $H$ greater than $5 \mathrm{~m}$ were larger in the $45-46$ years restoration period $(54 \%$ and $77 \%$ respectively) than in the old growth forest $(41 \%$ and $63 \%$ respectively) (Chen et al. 2019). The greatest values of $\mathrm{DBH}$ and $H$ in the 45-46 years restoration period may be because Pinus massoniana, as the dominant species, is a fast-growing heliophilous plant that gets more light by increasing vertical growth $(H)$ (Cheng et al. 2011).

Soil SOC, TN, AN, and AP contents were leading factors in stimulating the increase in biomass, $\mathrm{DBH}$, and $H$ (Fig. 3). As the environmental basis for vegetation survival, improving the soil provides a better habitat and essential nutrients for vegetation growth (Huang et al. 2018), ultimately promoting the positive succession of vegetation (Liang et al. 2010). The accumulation of SOC affects biomass, $\mathrm{DBH}$, and $H$ mainly by decomposing and releasing large amounts of nutrients to meet plant growth needs, and by improving soil texture and promoting microbial activity which provide a better growing environment for vegetation (Alday et al. 2012). Moreover, the increase in $\mathrm{N}$ content promotes growth of the leaf area and improves plant photosynthesis, providing sufficient energy for the growth of individual plants. P is the nutrient that most limits productivity and species richness (Huang et al. 2015), and also controls leaf litter 
decomposition (Zeng et al. 2016). In addition, soil P changes the structure of the root system, promotes the formation and growth of fine roots, lateral roots and secretions of root exudates, and thereby stimulates plants to make more efficient use of soil nutrients (Li et al. 2017).

\section{Key factors affecting vegetation restoration}

Soil factors (pH, SOC, TN, TK, Mg, AN, and AP) and vegetation features (biomass, $\mathrm{DBH}$, and $H$ ) were the main factors influencing vegetation restoration at our study site. This is consistent with the finding that the recovery of degraded ecosystems not only relies on soil rehabilitation, but also on the reconstruction, productivity, and function of vegetation (Liang et al. 2010; Peng et al. 2012).

The soil properties and vegetation features can be viewed as three distinct groups. The first group can be summarized as soil $\mathrm{pH}, \mathrm{SOC}, \mathrm{TN}, \mathrm{AN}, \mathrm{AP}$, biomass, $\mathrm{DBH}$, and $H$ across the vegetation restoration periods. The roles of soil $\mathrm{pH}, \mathrm{SOC}, \mathrm{TN}, \mathrm{AN}$, and AP have been analyzed above. Specifically, soil resource is the main limiting factor in the early period of vegetation restoration. However, in the later period of vegetation restoration, the change in community characteristics leads to light conditions becoming a limiting factor (van Der Maarel and Franklin 2013). With the accumulation of biomass, a complex community structure reduces the understory light transmittance, controlling the vegetation in the understory including the growth and mortality of tree seedlings and saplings (Montgomery and Chazdon 2001). Therefore, the shade tolerant species are successively established, increasing understory vegetation richness. On the other hand, heliophilous species are shaped by increasing $H$ and diameter to gain more light by adapting to strong interspecific competition. At increasingly larger $H$ and $\mathrm{DBH}$, light transmittance could further influence a species' light-capturing ability and distribution (Cheng et al. 2011). The limitation of light conditions for vegetation growth and performance in the late vegetation restoration period means that increases in biomass, $\mathrm{DBH}$, and $H$ are the key growth factors, determining restoration success.

The second group of soil variables includes Mg. The increase in $\mathrm{Mg}$ during the restoration periods was accompanied by a series of improvements in the plants' physiological processes, such as photosynthetic efficiency, carbohydrate metabolism, and synergistic absorption with P (Unger 2010). The third group showed that the vegetation restoration development was determined by TK. Besides N and P, K is the limiting nutrient with a significant influence on vegetation growth and development (Pang et al. 2018), mainly reflected in the impact on plant photosynthesis and respiration by controlling the regulation of stomata opening (Unger 2010), even though here the effect of TK on vegetation development was not significant.

Previous studies have suggested that species diversity was the dominant vegetation factor for vegetation restoration in a large scale (Crouzeilles et al. 2016), because higher species richness can enhance ecosystem stability and increase nutrient use efficiency ( $\mathrm{Hu}$ et al. 2017). However, species diversity was not considered to be an influential factor for vegetation restoration in our study. The difference could be due to the non-significance of the relationships between species diversity and the main soil physicochemical properties or biomass, indicating that species diversity had no significant effect on the recovery of soil fertility and plant communities at our study site. In addition, species diversity showed a decreasing trend in the 45-46 years restoration period (Fig. 2), in which dominant species transformed from simple shrubs and herbs to pioneer species such as Pinus massoniana. In fact, needles of some Pinus species have been reported as a hindering factor which influences the regeneration of native plants and increases in species diversity (NavarroCano et al. 2010). It is reasonable that species diversity has no significant effect on vegetation restoration in specific study area, but further research is needed.

\section{Soil and vegetation factors affecting biomass}

The variation of biomass was one of the important indexes reflecting vegetation restoration (Mansourian et al. 2005). Therefore, the relative importance of soil properties and vegetation features in driving biomass development can reflect the degree of their individual and joint influence on vegetation restoration.

Our study revealed that the change in biomass was strongly influenced by the interaction of soil properties and vegetation features, which explained $55.55 \%-72.32 \%$ of the biomass variation (Fig. 4). This dominant contribution by joint influence to biomass may be explained by the close interaction between vegetation and soil (Liang et al. 2010). As we discussed above, there was a clear co-evolutionary relationship between soil factors $(\mathrm{pH}, \mathrm{SOC}, \mathrm{TN}, \mathrm{AN}$, and $\mathrm{TP})$ and vegetation features (DBH and $H$ ) across the restoration periods. This result suggests that the variations in key soil factors $(\mathrm{pH}, \mathrm{SOC}$, $\mathrm{TN}, \mathrm{AN}$, and TP) were likely to promote the growth of plant and the restoration of vegetation structure (Alday et al. 2012). In turn, vegetation features (DBH, and $H$ ) could influence improvements in the soil environment (Fig. 3). These results also offer the further evidence for the hypothesis that the mechanisms of plant and soil promote vegetation restoration synergistically.

This study also found that soil properties explained $3.30 \%-31.44 \%$ of the variation in biomass, which was basically higher than explanation of vegetation $(5.09 \%-$ 24.32\%). This result provides evidence that the 
importance of soil properties in driving the changes observed in biomass is more than that of vegetation features in the study region, which is most likely because the advantage of hydrothermal conditions in the subtropical region accelerates the material circulation, and promotes the enrichment of soil organic matter (Corlett and Hughes 2015); thus, providing a fertile environment for plant growth. The regulation mechanism of soil properties on biomass development had been discussed previously. With vegetation restoration, the increased in plant species has intensified the competition of aboveground parts for light resources and underground roots for soil resources (Cheng et al. 2011; Li et al. 2017), which further induces the variations of individual growth and morphological structure of trees (DBH and $H$ ). As DBH and $H$ increased, more fine materials and litters can be intercepted and accumulated by plants, further enhancing the accumulation of biomass (Li et al. 2017).

The biomass development at our study site was influenced by different soil and vegetation factors in different restoration periods. In the early restoration period (4-5 years), SOC was the major influential factor (Table 4). The possibility is that SOC is the main source of most nutrients, and that the accumulation of SOC promotes improvements in other soil factors, such as TN, AN, and AP, which have a notable effect on vegetation growth and development (Alday et al. 2012). In the $4-5$ years restoration period, SOC content was low (Fig. 2), which is not conducive to the improvement of soil structure or the accumulation of nutrients (Bienes et al. 2016). Therefore, the low SOC not only limits the growth of plant roots, but also intensifies the contradiction between the demand of plant growth for water and nutrients and the supply of soil water and nutrients, resulting in hindrances to plant growth.

$H, \mathrm{pH}$, and AP were the main factors driving biomass development in the 10-12 years restoration period. This could be attributed to the competition of shrubs for light, which would drive the increasing of $H$ to adapt to interspecific competition (Cheng et al. 2011). Additionally, the accumulation of biomass impels plants to need more Nand P-rich substances (such as enzymes, transport proteins, and amino acids) to participate in metabolic activities (Qin et al. 2016). Therefore, shrubs need to absorb more $\mathrm{N}$ and $\mathrm{P}$ for growth than do herbs. In particular, $\mathrm{P}$ is an important limited factor in red soil area of south China (Gao et al. 2014). However, in the 10-12 years restoration period, the increasing of $\mathrm{pH}$ affected the availability of $\mathrm{P}$ (Duan et al. 2008), suggesting that the role of AP may intensity the inequity of competition among plants, rather than promote the accumulation of biomass.

Biomass in the $45-46$ years restoration period was conditioned by the synergistic effect of $H$ and $\mathrm{pH}$. The significant effects of $H$ and $\mathrm{pH}$ may be caused by a combination of two factors. Firstly, the dominant tree species (Pinus massoniana) of 45-46 years restoration period obtains more light by increasing $H$ and canopy density (Cheng et al. 2011), resulting in lower density of woody plants (Table 1); thus, $H$ had a negative effect on biomass. Secondly, low soil $\mathrm{pH}$ is beneficial to improve soil permeability, aggregates and porosity (such as BD), and the accumulation of soil nutrients (such as SOC, N and P) (Ramírez et al. 2015), and enhances the availability of $\mathrm{P}, \mathrm{K}, \mathrm{Ca}$, and $\mathrm{Mg}$ (Duan et al. 2008). Meanwhile, soil pH decreased with vegetation restoration, and the bioaccumulation and material circulation increased with advantageous hydrothermal conditions (Corlett and Hughes 2015), which were beneficial to the increment of soil nutrient content; thus restoration stimulates the increase of biomass.

In the old growth forest (sub-climax community), the structure of plant community has reached a state of stable (Peng et al. 2012), which means that the development of vegetation features (DBH and $H$ ) has entered a slow growth stage and has less of an impact on biomass. Instead, as a nutrient bank and soil health indicator (Bienes et al. 2016), SOC continues to influence biomass growth. In addition, evergreen trees with a long leaf life need to accumulate more organic substances (such as lignin) to construct defensive structures, and require higher $\mathrm{N}$ and $\mathrm{P}$ content to maintain normal growth and metabolism (Zeng et al. 2016). Therefore, the supply capacity of soil $\mathrm{N}$ and $\mathrm{P}$ largely determines the effectiveness of vegetation restoration ( $\mathrm{Li}$ et al. 2012a).

\section{Conclusions}

The present work has shown that vegetation restoration can improve significantly soil texture and fertility (especially N, P, and SOC) and vegetation features (species diversity, biomass, $\mathrm{DBH}$, and $H$ ). The study showed a clear coupling relationship between some soil factors $(\mathrm{pH}$, SOC, TN, AN, and TP) and vegetation development and structural components (biomass, $\mathrm{DBH}$, and $H$ ). At the same time, soil properties and vegetation features had a strongly cooperative influence on the variation of biomass, which suggested that the successful restoration of a degraded forest was driven mainly by their synergistic effect. The individual effect of soil factors on biomass development was greater than that of vegetation factors. Notably, the controlling factors of biomass had differed in the different restoration periods.

\section{Abbreviations}

AK: Available potassium; AN: Alkaline hydrolysis nitrogen; AP: Available phosphorus; BD: Bulk density; Ca: Total calcium; DBH: Diameter at breast height; K: Potassium; Mg: Total magnesium; MODIS: Moderate Resolution Imaging Spectroradiometer; N: Nitrogen; P: Phosphorus; PCA: Principal component analysis; $R^{2}$ : Adjustment decision coefficient; SOC: Soil organic carbon; SRA: Stepwise regression analysis; H: Height; TK: Total potassium; TN: Total nitrogen; TP: Total phosphorus 


\section{Acknowledgments}

We thank the administrative staff at the Dashanchong Forest Farm, Changsha County, Hunan Province, for their support.

\section{Authors' contributions}

$X F$ and $C C$ designed the idea and study, and coordinated the manuscript preparation. CC, XF, WX, PL, SO, and YK processed the data and analyzed the results. CC, XF, WX, and YK contributed to the manuscript writing and editing. All authors read and approved the final manuscript.

\section{Funding}

This work was supported by the National Forestry Public Welfare Industry Research Project (grant no. 201504411) and the National Natural Science Foundation of China (grant nos. 31570447 and 31300524).

\section{Availability of data and materials}

The datasets generated and/or analyzed during the current study are not publicly available due [the data is a part of the author's graduation thesis] but are available from the corresponding author on reasonable request.

\section{Ethics approval and consent to participate}

Not applicable.

\section{Consent for publication}

Not applicable.

\section{Competing interests}

The authors declare that they have no competing interests.

\section{Author details}

${ }^{1}$ Faculty of Life Science and Technology, Central South University of Forestry and Technology, Changsha 410004, China. ${ }^{2}$ Huitong National Field Station for Scientific Observation and Research of Chinese Fir Plantation Ecosystem in Hunan Province, Huitong 438107, China. ${ }^{3}$ Department of Soil Science of Temperate Ecosystems, Georg-August University of Gottingen, 37077 Göttingen, Germany. ${ }^{4}$ Department of Agricultural Soil Science, Georg-August University of Gottingen, 37077 Göttingen, Germany.

\section{Received: 18 November 2019 Accepted: 17 April 2020}

\section{Published online: 08 May 2020}

\section{References}

Alday JG, Marrs RH, Martínez-Ruiz C (2012) Soil and vegetation development during early succession on restored coal wastes: a six-year permanent plot study. Plant Soil 353(1-2):305-320

Armstrong JS (1967) Derivation of theory by means of factor analysis or tom swift and his electric factor analysis machine. Am Stat 21(5):17-21 http:// repository.upenn.edu/marketing_papers/13. Accessed 15 Dec 2019

Ayma-Romay Al, Bown HE (2019) Biomass and dominance of conservative species drive above-ground biomass productivity in a mediterranean-type forest of Chile. For Ecosyst 6:47. https://doi.org/10.1186/s40663-019-0205-z

Berthrong ST, Jobbágy EG, Jackson RB (2009) A global meta-analysis of soil exchangeable cations, $\mathrm{pH}$, carbon, and nitrogen with afforestation. Ecol Appl 19(8):2228-2241

Bienes R, Marques MJ, Sastre B, García-Díaz A, Ruiz-Colmenero M (2016) Eleven years after shrub revegetation in semiarid eroded soils. Influence in soil properties. Geoderma 273:106-114

Boix-Fayos C, de Vente J, Albaladejo J, Martínez-Mena M (2009) Soil carbon erosion and stock as affected by land use changes at the catchment scale in Mediterranean ecosystems. Agric Ecosyst Environ 133(1-2):75-85

Brandies T, Randolph KD, Strub M (2009) Modeling Caribbean tree stem diameters from tree height and crown width measurements. Math Comput For Nat-Res Sci 1(2):78-85

Bremner JM (1996) Nitrogen-total. In: Sparks DL (ed) Methods of soil analysis. Part 3: chemical methods, SSSA book series 5. Soil Science Society of America, Madison, pp 1085-1121

Chang CC, Turner BL (2019) Ecological succession in a changing world. J Ecol 107:503-509

Chen JL, Fang X, Gu X, Li LD, Liu ZD, Wang LF, Zhang SJ (2019) Composition, structure, and floristic characteristics of two forest communities in the
Central-Subtropical China. Scientia Silvae Sinicae 55(2):159-172 (in Chinese with English abstract)

Cheng XP, Kiyoshi U, Tsuyoshi H, Shao PY (2011) Height growth, diameter-height relationships and branching architecture of Pinus massoniana and Cunninghamia lanceolatain early regeneration stages in Anhui Province, eastern China: effects of light intensity and regeneration mode. For Stud China 13(1):1-12

Corlett RT, Hughes AC (2015) Subtropical forests. In: Peh KSH, Corlett RT, Bergeron Y (eds) The Routledge handbook of forest ecology. Routledge, Oxford, pp 46-55

Crouzeilles R, Curran M, Ferreira MS, Lindenmayer DB, Grelle CEV, Benayas JMR (2016) A global meta-analysis on the ecological drivers of forest restoration success. Nat Commun 7:11666

Demenois J, Rey F, Ibanez T, Stokes A, Carriconde F (2018) Linkages between root traits, soil fungi and aggregate stability in tropical plant communities along a successional vegetation gradient. Plant Soil 424(1-2):319-334

Duan WJ, Ren H, Fu SL, Guo QF, Wang J (2008) Pathways and determinants of early spontaneous vegetation succession in degraded lowland of South China. J Integr Plant Biol 50(2):147-156

Gao Y, He NP, Yu GR, Chen WL, Wang QF (2014) Long-term effects of different land use types on $\mathrm{C}, \mathrm{N}$, and $\mathrm{P}$ stoichiometry and storage in subtropical ecosystems: a case study in China. Ecol Eng 67:171-181

Gu X, Fang X, Xiang WH, Zeng YL, Zhang SJ, Lei PF, Peng CH, Kuzyakov Y (2019) Vegetation restoration stimulates soil carbon sequestration and stabilization in a subtropical area of southern China. Catena 181:104098. https://doi.org/ 10.1016/j.catena.2019.104098

Hooper DU (1998) The role of complementarity and competition in ecosystem responses to variation in plant diversity. Ecology 79(2):704-719

Hu F, Du H, Zeng FP, Peng WX, Song TQ (2017) Plant community characteristics and their relationships with soil properties in a karst region of Southwest China. Contemp Probl Ecol 10(6):707-716

Huang FF, Zhang WQ, Gan XH, Huang YH, Guo YD, Wen XY (2018) Changes in vegetation and soil properties during recovery of a subtropical forest in South China. J Mt Sci 15(1):46-58

Huang YT, Ai XR, Yao L, Zang RG, Ding Y, Huang JH, Feng G, Liu JC (2015) Changes in the diversity of evergreen and deciduous species during natural recovery following clear-cutting in a subtropical evergreen-deciduous broadleaved mixed forest of Central China. Trop Conserv Sci 8(4):1033-1052

Huang ZY, Chen J, Ai XY, Li RR, Ai YW, Li W (2017) The texture, structure and nutrient availability of artificial soil on cut slopes restored with OSSS influence of restoration time. J Environ Manag 200:502-510

Hunan Provincial Department of Agriculture (1989) Hunan soil. Agriculture Press, Beijing (in Chinese with English abstract)

Institute of Soil Science, Chinese Academy of Sciences (1978) The analysis of soil physical-chemical properties. Shanghai scientific and Technical Publishers, Shanghai (in Chinese with English abstract)

IUSS Working Group WRB (2006) World reference base for soil resources 2006: a framework for international classification, correlation and communication. http:// www.ige.unicamp.br/pedologia/wsrr103e.pdf: 2006. Accessed 15 Dec 2019

Jain A, Nandakumar K, Ross A (2005) Score normalization in multimodal biometric systems. Pattern Recogn 38(12):2270-2285

Li DJ, Niu SL, Luo YQ (2012a) Global patterns of the dynamics of soil carbon and nitrogen stocks following afforestation: a meta-analysis. New Phytol 195(1): 172-181

Li JY, Xu RK, Zhang H (2012b) Iron oxides serve as natural anti-acidification agents in highly weathered soils. J Soils Sediments 12(6):876-887

Li QX, Jia ZQ, Liu T, Feng LL, He LXZ (2017) Effects of different plantation types on soil properties after vegetation restoration in an alpine sandy land on the Tibetan plateau, China. J Arid Land 9(2):200-209

Liang J, Wang XA, Yu ZD, Dong ZM, Wang JC (2010) Effects of vegetation succession on soil fertility within farming-plantation ecotone in Ziwuling mountains of the loess plateau in China. Agr Sci China 9(10):1481-1491

Liu WW, Xiang WH, Tian DL, Yan WD (2010) General allometric equations for estimating Cunninghamia lanceolata tree biomass on large scale in southern China. J Cent South Univ Forest T 30(4):7-14 (in Chinese with English abstract)

Madonsela S, Cho MA, Ramoelo A, Mutanga O, Naidoo L (2018) Estimating tree species diversity in the savannah using NDVI and woody canopy cover. Int J Appl Earth Obs 66:106-115

Mansourian S, Vallauri D, Dudley N (2005) Forest restoration in landscapes: beyond planting trees. Springer Science \& Business Media, New York 
Montgomery RA, Chazdon RL (2001) Forest structure, canopy architecture, and light transmittance in tropical wet forests. Ecology 82(10):2707-2718

Navarro-Cano JA, Barberá GG, Castillo VM (2010) Pine litter from afforestations hinder the establishment of endemic plants in semiarid scrubby habitats of Natura 2000 network. Restor Ecol 18(2):165-169

Nicia P, Bejger R, Zadrożny P, Sterzyńska M (2018) The impact of restoration processes on the selected soil properties and organic matter transformation of mountain fens under Caltho-Alnetum community in the Babiogórski National Park in outer Flysch Carpathians, Poland. J Soils Sediments 18(8): $2770-2776$

Olsen SR, Watanabe FS, Bowman RA (1983) Evaluation of fertilizer phosphate residues by plant uptake and extractable phosphorus. Soil Sci Soc Am J 47(5):952-958

Ouyang S, Xiang WH, Wang XP, Zeng YL, Lei PF, Deng XW, Peng CH (2016) Significant effects of biodiversity on forest biomass during the succession of subtropical forest in South China. Forest Ecol Manag 372:291-302

Pang DB, Cao JH, Dan XQ, Guan YH, Peng XW, Cui M, Wu XQ, Zhou JX (2018) Recovery approach affects soil quality in fragile karst ecosystems of Southwest China: implications for vegetation restoration. Ecol Eng 123:151160

Peng WX, Song TQ, Zeng FP, Wang KL, Du H, Lu SY (2012) Relationships between woody plants and environmental factors in karst mixed evergreendeciduous broadleaf forest, Southwest China. J Food Agric Environ 10:890896

Qin J, Xi WM, Rahmlow A, Kong HY, Zhang Z, Shangguan ZP (2016) Effects of forest plantation types on leaf traits of Ulmus pumila and Robinia pseudoacacia on the loess plateau, China. Ecol Eng 97:416-425

R Development Core Team (2016) R: a language and environment for statistical computing. R Foundation for Statistical Computing, Vienna https://wwwRprojectorg/. Accessed 15 Dec 2019

Ramírez JF, Fernandez Y, González PJ, Salazar X, Iglesias JM, Olivera Y (2015) Influence of fertilization on the physical and chemical properties of a soil dedicated to the production of Megathyrsus maximus seed. Pastos y Forrajes 38(4):479-486

Roem WJ, Klees H, Berendse F (2002) Effects of nutrient addition and acidification on plant species diversity and seed germination in heathland. J Appl Ecol 39(6):937-948

Takoutsing B, Weber JC, Tchoundjeu Z, Shepherd K (2016) Soil chemical properties dynamics as affected by land use change in the humid forest zone of Cameroon. Agrofor Syst 90(6):1089-1102

Unger MA (2010) Relationships between soil chemical properties and forest structure, productivity and floristic diversity along an altitudinal transect of moist tropical forest in Amazonia, Ecuador. Georg-August-Universität Göttingen, Dissertation

van Breemen N, Driscoll CT, Mulder J (1984) Acidic deposition and internal proton sources in acidification of soils and waters. Nature 307:599-604

van Der Maarel E, Franklin J (2013) Vegetation ecology, 2nd edn. Wiley-Blackwell, Oxford

van der Putten WH, Bardgett RD, Bever JD, Bezemer TM, Casper BB, Fukami T, Kardol P, Klironomos JN, Kulmatiski A, Schweitzer JA, Suding KN, Van de Voorde TFJ, Wardle DA (2013) Plant-soil feedbacks: the past, the present and future challenges. J Ecol 101(2):265-276

Wang D, Zhang B, Zhu LL, Yang YS, Li MM (2018a) Soil and vegetation development along a 10-year restoration chronosequence in tailing dams in the Xiaoqinling gold region of Central China. Catena 167:250-256

Wang N, Zhu XY, Fang X, Gu X, Chen JL (2018b) The variation of soil organic carbon and soil particle-sizes in different degraded forests in the subtropical region. J Soil Water Conserv 32(3):218-225 (in Chinese with English abstract)

Xiang WH, Liu SH, Lei XD, Frank SC, Tian DL, Wang GJ, Deng XW (2013) Secondary forest floristic composition, structure, and spatial pattern in subtropical China. J For Res 18(1):111-120

Xiang WH, Zhou J, Ouyang S, Zhang SL, Lei PF, Li JX, Deng XW, Fang X, Forrester $\mathrm{DI}$ (2016) Species-specific and general allometric equations for estimating tree biomass components of subtropical forests in southern China. Eur J Forest Res 135(5):963-979

Xu CH, Xiang WH, Gou MM, Chen L, Lei PF, Fang X, Deng XW, Ouyang S (2018) Effects of forest restoration on soil carbon, nitrogen, phosphorus, and their stoichiometry in Hunan, southern China. Sustainability 10(6):1874

Yang T, Adams JM, Shi Y, He JS, Jing X, Chen LT, Tedersoo L, Chu HY (2017) Soil fungal diversity in natural grasslands of the Tibetan plateau: associations with plant diversity and productivity. New Phytol 215(2):756-765
Zeng QC, Li X, Dong YH, An SS, Darboux F (2016) Soil and plant components ecological stoichiometry in four steppe communities in the loess plateau of China. Catena 147:481-488

Zhang YH, Xu XL, Li ZW, Liu MX, Xu CH, Zhang RF, Luo W (2019) Effects of vegetation restoration on soil quality in degraded karst landscapes of Southwest China. Sci Total Environ 650:2657-2665

\section{Submit your manuscript to a SpringerOpen ${ }^{\circ}$ journal and benefit from:}

- Convenient online submission

- Rigorous peer review

- Open access: articles freely available online

- High visibility within the field

- Retaining the copyright to your article

Submit your next manuscript at $\boldsymbol{\nabla}$ springeropen.com 